\title{
EUROPEJSKIE TOŻSAMOŚCI, MIGRACJA I INTEGRACJA. MLODZI EUROPEJSCY MIGRANCI W DWÓCH ZACHODNICH METROPOLIACH
}

\begin{abstract}
Bozzolo Sandro, Costamagna Christian, Fontana Luisa, Europejskie tożsamości, migracja $i$ integracja. Młodzi europejscy migranci w dwóch zachodnich metropoliach [European identities, migration and integration. Young European migrants in two Western metropolises] edited by J. Kubera, Ł. Skoczylas - "Człowiek i Społeczeństwo”, vol. XXXVII, Poznań 2014, pp. 161-171, Adam Mickiewicz University Press. ISBN 978-83-232-2764-9. ISSN 0239-3271.

This paper focuses on the perception of young migrants who relocated to two Western metropolises, London and Vienna. In its majority, the target group consists of young graduates, speaking one or more foreign languages, and generally animated by a cosmopolitan spirit. The studied group consists of 11 persons interviewed in London and Vienna. Moreover, the paper is based on interviews conducted with a group of 13 leaders of a European project about migrants (Re-Turn Project). The studied groups consists of both genders in their 20s. With the analytical instruments of psychology, sociology and politology, their behaviour toward integration will be explained, as well as the matters of identity, the appropriation of cultural space and the imagined European community, still under construction. After a period of experience as migrants in a multicultural context, most of them have begun to revalue their own ethnic identity and their desire to belong to a group in which they can share a language, culture and traditions.
\end{abstract}

Sandro Bozzolo, Università degli Studi di Genova, Dipartimento di Scienze della Formazione, Via Balbi 5, 16126 Genova, Italy.

Christian Costamagna, Università degli Studi del Piemonte Orientale, Dipartimento di Studi Umanistici, Via Duomo 6, 13100 Vercelli, Italy.

Luisa Fontana, Ordine Nazionale degli Psicologi, Piazza di Porta Pia 121, 00198 Roma, Italy.

\section{WSTĘP}

Celem niniejszego artykułu jest analiza nowego, występującego w Unii Europejskiej zjawiska migracyjnego, rozpatrywanego pod względem psychospołecznym, socjologicznym oraz politologicznym. Badania zostały 
przeprowadzone na grupie 11 młodych mieszkańców miast z wykształceniem wyższym, pochodzących z różnych krajów Europy, którzy po skonczeniu studiów wyemigrowali do dwóch stolic Europy Zachodniej: Londynu i Wiednia. Analiza badań została dodatkowo poparta zestawem 13 wywiadów, przeprowadzonych w Domadossoli (Włochy), podczas spotkania koordynatorów europejskiego projektu poświęconego migracji powrotnej "Central Europe Re-Turn Project”. Poniżej zamieszczamy krótki opis wykorzystanych źródeł.

Miasta, w których zostały przeprowadzone wywiady: Londyn, Wiedeń i Domodossola.

Okres badań: 2012-2013

Wiek badanych : 20-30 lat

Grupa badanych: 24 osoby, w tym:

Londyn: 8

narodowość: 3 Niemców, 2 Polaków, 2 Włochów, 1 Hiszpan płeć: 5 mężczyzn i 3 kobiety

Wiedeń: 3

narodowość: 1 Włoszka, 1 Francuz, 1 Ukrainka

płeć: 1 mężczyzna, 2 kobiety

Domodossola: 13 wywiadów przeprowadzonych wśród koordynatorów projektu „Re-Turn”, który ma na celu wspieranie powrotów emigrantów do ich ojczystych regionów, w szczególności emigrantów z Europy Wschodniej, którzy wyemigrowali do bogatszych i lepiej rozwiniętych państw Europy Zachodniej i Północnej.

Jak zauważymy, wachlarz możliwości współczesnego pokolenia wciąż się poszerza. Niemalże nieograniczona wolność przemieszczania się zapewnia coraz więcej możliwości interakcji. Pomimo to nowi migranci muszą nieuchronnie zmierzyć się z licznymi barierami zarówno kulturowymi, jak i językowymi, co często doprowadza ich do odkrycia w sobie większego poczucia przynależności do społeczności, z której pochodzą.

\section{PROFIL PSYCHOSPOŁECZNY}

Analizując dane zebrane podczas wywiadów przeprowadzonych wśród migrantów pod względem psychospołecznym, możemy zauważyć, że tożsamość etniczna, rozumiana jako poczucie przynależności do konkretnej 
grupy kulturowej, zyskuje szczególne znaczenie właśnie w kontekście wielokulturowości, w której niezwykle istotne jest zetknięcie się grup większości i mniejszości. W tym przypadku tożsamość etniczna staje się jedną z kategorii społecznych, umożliwiających zarówno definiowanie siebie, jak i odróżnianie się, co wynika z poniższego przykładu:

„Mam wrażenie, że jestem bardziej skupiona na polskości, na byciu Polką... Po przeprowadzce tutaj, niemieszkaniu w moim kraju, stałam się bardziej patriotyczna niż wtedy, gdy byłam tam... Myślę, że teraz czuję się bardziej Polką niż przedtem" (wywiad 1, Polka w Londynie).

Imigrant przybywający do nowego kraju musi skonfrontować się z dwoma różnymi systemami kulturowymi: grupy etnicznej, do której należy, oraz społeczności, która go przyjmuje. W tej sytuacji imigrant ma do wyboru kontinuum możliwości, począwszy od zachowania własnych zwyczajów, a skończywszy na przyjęciu nowego modelu życia.

Wielu autorów łączy badania nad tożsamością etniczną z badaniami dotyczącymi akulturacji, a zatem analizy zmian, które można odnotować $\mathrm{w}$ postawach kulturowych, wierzeniach, zachowaniach $\mathrm{w}$ momencie zetknięcia się dwóch kultur. Zmiany tożsamości etnicznej są jednak tą oznaką akulturacji, która skupia się na subiektywnym poczuciu przynależności do grupy etnicznej lub kulturowej, na podstawie dostrzegania w sobie określonych cech fizycznych, psychologicznych lub społecznych.

Bazując na modelu opracowanym przez Berry'ego (1990; 1997), spróbujmy przeanalizować wywiady przeprowadzone z imigrantami w europejskich metropoliach, aby zbadać nastawienie imigrantów do własnej kultury i do kultury kraju przyjmującego.

Według zaproponowanego modelu wybory członków grupy mniejszości mogą się różnić $w$ dwóch aspektach. Pierwszy odnosi się do związku z kulturą kraju pochodzenia - w tym przypadku możliwości wyboru różnicują się od zachowania tych związków do całkowitego ich porzucenia. Drugi aspekt dotyczy związku z kulturą kraju przyjmującego - tutaj wybór może oscylować pomiędzy odrzuceniem a przyjęciem.

Wychodząc z takich przesłanek teoretycznych, możemy wyróżnić cztery możliwe strategie akulturacji:

- integracja: charakteryzuje się zachowaniem kultury ojczystej i równocześnie przyjęciem kultury państwa przyjmującego,

- asymilacja: przewiduje wyłączne przyjęcie kultury oferowanej przez państwo przyjmujące i porzucenie kultury ojczystej,

- separacja: zakłada odrzucenie kultury kraju przyjmującego i zachowanie kultury ojczystej, 
- marginalizacja: charakteryzuje się porzuceniem kultury własnego kraju ojczystego i odrzuceniem kultury oferowanej przez nowe państwo.

Analizując wywiady przeprowadzone $\mathrm{z}$ opisaną grupą badanych, można zaobserwować, że:

- w pięciu wywiadach nie pojawiają się dane mające znaczenie dla celów naszej pracy,

- w czterech przypadkach wydaje się, że pojawiają się elementy wskazujące na strategię integracji, która charakteryzuje się zachowaniem kultury ojczystej i równoczesnym przyjęciem kultury kraju przyjmującego.

Zachowanie kultury ojczystej wynika z subiektywnego poczucia przynależności do miejsca pochodzenia, $\mathrm{z}$ utrzymywania kontaktu $\mathrm{z}$ rodziną i przyjaciółmi, a także z faktu śledzenia dzienników i programów telewizyjnych swojego kraju. Nabywanie kultury kraju przyjmującego, w tym wypadku kraju wielokulturowego, rodzi się natomiast z nawiązywania kontaktów z innymi, funkcjonującymi w danym miejscu społecznościami, z przywiązania się do miasta i ludzi, którzy w nim żyją, a przede wszystkim z docenienia możliwości, jakie oferuje nowe miasto, różnorodności kultur. Osoby zintegrowane potwierdzają, że śledzą także wiadomości w dziennikach i telewizji kraju przyjmującego.

Wydaje się, że z takiego podejścia wyłania się koncepcja człowieka jako jednostki wolnej, mogącej przemieszczać się tam, gdzie zechce. Poniżej przedstawiamy fragment wywiadu, w którym uwidocznia się strategia integracji:

„Przede wszystkim, kiedy tu przyjechałem, zakochałem się w mieście. Kochałem je...

Ale... To jest powód, dla którego zostałem. To miasto daje ci mnóstwo możliwości. Możesz z nich po prostu skorzystać, oczywiście - jeśli chcesz" (wywiad 2, Polak w Londynie).

Wydaje się, że w żadnym z wywiadów nie przejawia się postawa asymilacji, charakteryzująca się całkowitym przyjęciem kultury kraju przyjmującego i porzuceniem kultury własnego kraju pochodzenia.

W jednym wywiadzie przejawiają się elementy typowe dla postawy separacji, charakteryzującej się zachowaniem kultury ojczystej i odrzuceniem kultury kraju przyjmującego. Jak wynika z przeprowadzonego wywiadu, do elementów wskazujących na zachowanie kultury kraju pochodzenia należą: silne subiektywne poczucie przynależności do ojczyzny, tęsknota za domem, a także wrażenie znajdowania się $\mathrm{w}$ nieodpowiednim miejscu, silna potrzeba nauczenia swoich dzieci dorastających $\mathrm{w}$ kraju przyjmującym ojczystego języka oraz obawa, że mogą go one nie przyswoić. 
Odrzucenie kultury państwa przyjmującego przejawia się $\mathrm{w}$ niechęci prowadzenia rozmów z dziećmi w języku zamieszkiwanego kraju, w braku miejscowych przyjaciół oraz przewidywaniu, że nigdy nie będzie się ich miało, a także $\mathrm{w}$ trudnościach $\mathrm{z}$ poprawnym używaniem języka obcego, opanowywanego w celach komunikacyjnych, co z kolei skutkuje wciąż powracającym uczuciem frustracji.

„[...] Tak długo, jak tu żyję, jestem stęskniona za domem. Teraz muszę wracać do Polski co 3 miesiące, inaczej nie czuję się tutaj komfortowo. [...] Bardzo tęsknię za moim krajem, bardzo. Bardzo dużo opiekuję się, spędzam mnóstwo czasu z moimi dziećmi, ucząc je polskiego. Zajmuję się nimi, czytam im i mówię w zasadzie tylko po polsku. Cierpię, ponieważ one mówią do mnie głównie po angielsku i to jest dla mnie duży problem, dla mnie... Nie chcę mówić po angielsku. Odrzucam to. Nie sądzę, abym kiedykolwiek była w stanie nawiązać przyjaźń z kimś, kogo ojczystym językiem jest angielski. Migracja nie może być dla mnie wieczna, ponieważ jeśli umrę, moje ciało wróci do Polski" (wywiad 1, Polka w Londynie).

Na koniec, w jednym z wywiadów zdaje się przejawiać postawa marginalizacji, charakteryzująca się odrzuceniem kultury kraju przyjmującego i porzuceniem kultury kraju pochodzenia. Osoba, z którą przeprowadzono wywiad, nie wydaje się zainteresowana państwami samymi w sobie, a także ich ewentualnymi powiązaniami również na poziomie społeczno-kulturowym, lecz skupia się wyłącznie na wartościach uniwersalnych.

„Dużo podróżuję, mieszkałem w wielu europejskich miastach. Mam hiszpański paszport, ale nie jestem patriotą. Nie wierzę w państwa, rządy, w nic. Nie identyfikuję się z hiszpańską flagą ani z żadną inną tego typu rzeczą. Miłość i pokój na świecie są wszystkim" (wywiad 3, Hiszpan w Londynie).

Podsumowując, próbowaliśmy przeanalizować wywiady migrantów, używając podstaw teoretycznych zaproponowanych przez Berry'ego (1990; 1997). Zebrane dane wykazują przewagę strategii integracji, co może być powiązane z subiektywnym odczuciem wyższego poziomu życia migrantów.

Strategia separacji wydaje się natomiast powiązana z subiektywnym odczuciem niższego poziomu życia migrantów i brakiem zadowolenia z rzeczywistości, w której żyją. Strategia marginalizacji może się odnosić do wizji świata, w którym nie istnieją państwa, kultura narodowa i tożsamość, istnieją natomiast wspólne wartości - ponad wszelkimi granicami.

Istotny jest fakt, że $\mathrm{w}$ grupie badanych nie pojawiły się osoby, które wykorzystałyby strategię asymilacji. Mogło tak się stać na przykład dlatego, iż nasi rozmówcy przebywali poza granicami swojego rodzinnego kraju stosunkowo krótko i nie mieli czasu na asymilację. Możliwe również, że osoby 
zasymilowane nie postrzegają siebie jako „imigrantów skądś”, lecz uznają się np. za „londyńczyków” lub nawet „Brytyjczyków” czy "Anglików”. $\mathrm{W}$ takim przypadku po prostu nie wzięły one udziału w naszym badaniu, które skierowane było do młodych imigrantów.

\section{PERSPEKTYWA SOCJOLOGICZNA}

Istnienie grupy migrantów, do której się odnosimy, jest rezultatem powstania Unii Europejskiej, za czym stoją idee kosmopolityzmu (Habermas 1998). Jednocześnie jednak opisywani tu migranci są budowniczymi zjednoczonej Europy, to oni bowiem określają w znacznej mierze współczesny charakter europejskiego projektu.

Mowa tu o tak zwanym "pokoleniu Erasmus" (Bettin Lattes, Bontempi 2011), które na początku mogło korzystać z nieograniczonych praw obywatelskich i swobodnej mobilności europejskiej, a które dziś ma swój udział w pewnego rodzaju "zawieszonej migracji”, w której postrzeganie siebie jako „obywateli Europy” jest jeszcze niepełne, natomiast tożsamość lokalna, regionalna i narodowa, tymczasowo porzucona na korzyść nowego „bycia Europejczykiem", czasami pojawia się w czasie emigracji. Wielką rolę odegrała $\mathrm{w}$ tym procesie także wciąż rosnąca popularność nowych środków komunikacji, które wspomogły popularyzację silnych cech ponadnarodowych. Nie spowodowało to osłabienia poczucia przynależności do poszczególnych wspólnot, ale przyczyniło się do rozpowszechnienia wizerunku siebie jako mieszkańca dużej europejskiej metropolii.

Docelowa grupa badanych w dużej części odpowiada modelowi migranta ponadnarodowego, który, tak jak opisał to Schiller (1994), znajduje się jednocześnie zarówno w środowisku emigracji, jak i imigracji, zawieszony pomiędzy dwiema (lub więcej) przestrzeniami komunikacyjnymi i symbolicznymi, które są bezustannie aktywne. Większość respondentów deklaruje, że czyta $\mathrm{w}$ Internecie prasę codzienną swojego kraju, regularnie korzysta z programu Skype lub innych komunikatorów internetowych, które zapewniają możliwość stałego kontaktu ze światem emocjonalnym i uczuciowym miejsca pochodzenia, i ostatecznie większość z nich określa się "Polakiem w Wiedniu" lub „Słowakiem w Europie”.

O ile opisany powyżej model można by zastosować do większości współczesnych migrantów, o tyle niektóre jego elementy możemy zauważyć również $\mathrm{w}$ przypadku opisywanej grupy badanych, złożonej głównie z młodzieży zainspirowanej najbardziej kosmopolitycznymi państwami Europy i międzynarodowymi możliwościami, jakie mogą w nich odnaleźć. Być 
może nie powinniśmy mówić w tym przypadku o „ucieczce” przed zamknięciem w strukturze ograniczonej kulturowo, o jednolitej tradycji, faktem jest jednak, że ci młodzi migranci dążą do urzeczywistnienia nie do końca sprecyzowanej wizji poszerzania horyzontów. Miałoby się to rozegrać na arenie europejskiej, a nie narodowej czy miejskiej. Dzięki temu możliwe stałoby się przeżycie czegoś pomiędzy tym, co Edward Shils definiował jako "chęć bycia nowoczesnym", a tym, co Mazzini nazywał "potrzebą istnienia i posiadania imienia" (Serra 2011).

Osoby, o których mowa w niniejszym badaniu, można również przypisać do kategorii „współczesnych”, przedstawionej przez filozofa i socjologa Alfreda Schütza (1962). Według niego tym terminem należałoby określić ogół osób, które „funkcjonują w tym samym czasie, ale nie w tej samej przestrzeni, żyją (mniej więcej) w tym samym okresie historycznym i mają ze sobą kontakt, często przelotny, ale nie spotykają się" (Schütz 1962).

„Na początku, gdy się tu przeniosłam, podobało mi się życie tutaj i nie kontaktowałam się z moimi przyjaciółmi tak często, jak czynię to teraz. [...] Myślę, że każdy, z kim rozmawiam, czuje się trochę samotny i odczuwa prawdziwą tęsknotę za domem. Więc najlepiej jest wtedy, gdy wskakuję do samolotu i jestem z powrotem" (wywiad 1, Polka w Londynie).

Wydaje się, że tym, czego w tej nowej rzeczywistości często brakuje, jest proces emocjonalnego "przywłaszczenia” międzynarodowej przestrzeni, którą oferują miasta będące celem migracji młodych ludzi. Naturalną konsekwencją tej sytuacji jest powszechne poczucie zagubienia, stojące w pewnym sensie $\mathrm{w}$ opozycji do uniwersalistycznych przesłanek, jakie przekonały młodych do budowania swojej przyszłości w innym miejscu, które wcześniej nie było postrzegane jako "gdziekolwiek", ale jako integralna część powiększonej wspólnoty.

Pewnego klucza ułatwiającego zrozumienie fenomenu nie-przywłaszczenia, dotykającego młodych migrantów w głównych metropoliach Europy Zachodniej, można doszukać się, obserwując międzynarodowy rynek pracy, do którego dołączają absolwenci-imigranci.

Warto tutaj przypomnieć, że zjawisko migracji, nie tylko w niedalekiej przeszłości, ale też obecnie, charakteryzuje się często dość jednolitą strukturą, której dane elementy są uszeregowane według zasad kategoryzacji poszczególnych tożsamości. Bardzo łatwo może to doprowadzić do etnicyzacji niektórych kategorii zawodowych. Wystarczy w tym miejscu wspomnieć o filipińskich pomocach domowych we Włoszech lub o "polskim hydrauliku". 
Głównym skutkiem takiej kategoryzacji jest postrzeganie siebie jako członka danej grupy i przypisywanie jej jakiegoś znaczenia. W przypadku opisywanej przez nas grupy taka zależność pomiędzy tożsamością etniczną i tożsamością zawodową nie występuje, a wiele miejsc pracy, w których zostają zatrudnieni migranci, zyskuje charakter coraz bardziej międzynarodowy.

Organizacje pozarządowe, wielkie firmy wielonarodowe, instytucje europejskie i niektóre centra edukacji stanowią konkretne przykłady miejsc, w których masowo zatrudniają się młodzi cudzoziemcy, pochodzący głównie $\mathrm{z}$ różnych państw europejskich, często zapoznani już z ideą kosmopolityzmu dzięki wcześniejszym doświadczeniom, takim jak na przykład studia zagraniczne. Co za tym idzie, pozycja „cudzoziemca” nagle przestaje istnieć, zostaje zastąpiona poczuciem normalności i naturalności $\mathrm{w}$ stosunku do środowiska, w którym funkcjonują osoby o podobnych doświadczeniach, możliwościach i poglądach.

\begin{abstract}
„Dla mnie, w Europie, nigdy nie czułem, że... Tak, jest mnóstwo różnic pomiędzy moim krajem a wieloma krajami w Europie, w których byłem, ale czułem, że system jest mniej lub bardziej podobny u nas. Może język się zmienia, ale ludzie myślą mniej więcej to samo. Tak więc nigdy nie czułem się nieswój, nigdy nie tęskniłem za domem. Choć prawdą jest, że gdy byłem w Rosji lub na Ukrainie, z powodu tych różnic w mentalności, to tak, czasem czułem się trochę nie na swoim miejscu, nie na właściwym miejscu, jakbym powinien mieszkać gdzie indziej, ponieważ to nie jest mój sposób myślenia. Więc czułem się, jakbym był w niewłaściwym miejscu. Ale w Europie nie czułem takich zmian" (wywiad 4, Francuz w Wiedniu).
\end{abstract}

„Chyba czuję się bardziej Niemcem niż Europejczykiem, ponieważ sądzę, że trudno jest zidentyfikować Europę jako całość. Mogę cieszyć się z tego, że podróżowanie nie jest już tak trudne [...], ale myślę, że Europa jako unia polityczna ma obecnie całe mnóstwo problemów. Nie uznaję Europy za całość, ale cieszę się z jej dobrodziejstw. Na przykład z bezpieczeństwa: nigdy nie poznałem wojny, ponieważ pomiędzy krajami panują dobre relacje" (wywiad 5, Niemiec w Londynie).

Mowa tu o odczuciu, które niejako zaprzecza traktowaniu migracji jako traumatycznego przeżycia, doświadczenia, które dotąd - poprzez zmianę położenia geograficznego, pozycji społecznej, a także zmianę pracy - mogło wpłynąć na sposób postrzegania świata. Konsekwencją uznawania siebie za migranta $w$ zaledwie niewielkim stopniu jest to, że $w$ procesie migracji nie tylko traci się dom, ale także poczucie jego braku. Kosmopolityczny wymiar miast wybieranych przez migrującą młodzież, $\mathrm{w}$ połączeniu $\mathrm{z}$ procesem kształcenia i dorastania młodzieży europejskiej w duchu ciągłej mobilności, 
zapewnia młodym poczucie przynależności do większej wspólnoty i ułatwia rozpoznawanie siebie jako jej części.

Doświadczenia młodych absolwentów, przemieszczających się z różnych regionów Europy $\mathrm{w}$ kierunku głównych miast kontynentu, sugerują, że mamy do czynienia z nieukończonym jeszcze podziałem wspólnej przestrzeni, który wciąż się rozwija. Większości młodych migrantów Europy międzynarodowe doświadczenia w Londynie czy Wiedniu przypominają te, które James Clifford (1994) zdefiniował jako „wspólny dom z dala od domu", a więc jako możliwą do poznania i już poznaną przestrzeń wspólną, która może jednak wywołać poczucie odległości i obcości.

\section{REFLEKSJE PODSUMOWUJĄCE}

Jak dowiedziono, z analizy wywiadów wyłania się wyraźnie problem natury politycznej, powiązany z przynależnością narodową obywateli Europy migrujących wewnątrz kontynentu europejskiego.

$\mathrm{W}$ przeszłości państwa wielonarodowe, poza nielicznymi wyjątkami, ulegały silnym naciskom i nierzadko dochodziło w nich do rozłamów. Wystarczy przywołać rozpad Imperium Habsburgów, Imperium Osmańskiego, a także bardziej współcześnie - Jugosławii, Związku Radzieckiego lub Czechosłowacji. Poza tym, pomimo nielicznych dobrych przykładów, do jakich należy Szwajcaria, również Belgia i Kanada, cierpią one z tego samego powodu: konfliktów pomiędzy różnymi narodowościami współzamieszkującymi jedno państwo.

Zjawisko, które niewątpliwie narodziło się w epoce modernizmu „wspólnoty wyobrażone” (Anderson 1983) - dało początek fenomenowi nacjonalizmu (Gellner 1983), który stał się głównym narzędziem legitymizacji politycznej. Kraje Europy przyjęły bez zastrzeżeń proces tworzenia się narodowych wspólnot wyobrażonych, których następstwem po II wojnie światowej jest eksperyment europejski. Wyobrażona Europa, nawet w swojej postaci federalnej, niekoniecznie zakłada istnienie Europejczyka. W rzeczywistości Europa jest kolebką różnych społeczności, języków, kultur, które bardzo trudno byłoby wykorzenić na korzyść jednej (zwierzchniej) kultury ogólnoeuropejskiej, o ile w ogóle istnieje taka możliwość i taka potrzeba, aby realizować ten projekt. Unia Europejska jeszcze na początku XXI wieku była $\mathrm{w}$ pewnym sensie zakładnikiem narodowych opinii publicznych - wystarczy poczytać gazety z różnych krajów europejskich, aby zdać sobie z tego sprawę. Wielka Brytania zastanawia się, czy nie odstąpić od Unii, południe Europy skarży się na zbytnie wymagania finansowe nałożone przez Brukselę 
i ma nadzieję na większą elastyczność w kwestii długu publicznego. Niemcy natomiast kontynuują dotychczasową linię działania, aby zapewnić sobie większą stabilizację. Jakby tego nie było dosyć, Katalonia i Szkocja dążą do uzyskania niepodległości. Ciężki kryzys społeczny i ekonomiczny stanowiący prawdziwy węzeł gordyjski pogłębił starcia pomiędzy państwami Europy i poddał $w$ wątpliwość trwałość projektu europejskiego. Czy powraca widmo nacjonalizmu?

Młodzi Europejczycy, zainspirowani duchem otwartości i kosmopolityzmu, po przeprowadzce z różnych państw Unii Europejskiej do głównych metropolii Europy Zachodniej, w zdecydowanej większości przypadków docenili istotę swojej przynależności narodowej. Trudności językowe i kulturowe wywołały $\mathrm{w}$ respondentach silniejsze poczucie przynależności do społeczności, z której się wywodzą.

Osoby poddane badaniu nie odrzucają swojej tożsamości europejskiej, traktowanej jako pewna wartość, jednak w prawie wszystkich przypadkach przynależność narodowa przeważa nad europejską. Choć Unia Europejska zapewniła Europejczykom swobodę poruszania się, pokój, a także wyższy standard życia, to większość osób biorących udział w badaniu uznaje jednak, że bardziej korzystnym dla nich rozwiązaniem, zarówno pod względem kulturowym, symbolicznym, jak i uczuciowym, jest powrót do swojej ziemi ojczystej.

Należy podkreślić, iż dane z wywiadów przeprowadzonych w Londynie i Wiedniu, przekrojowo przedstawione $\mathrm{w}$ niniejszej pracy, zostały całkowicie potwierdzone przez wywiady przeprowadzone $\mathrm{w}$ Domodossoli $\mathrm{z}$ koordynatorami projektu europejskiego "Re-Turn”. Najistotniejsze z nich to: wzmożone poczucie tożsamości etnicznej i narodowej migrantów, a także przewaga wartości tożsamości narodowej nad europejską.

Pomimo znaczących wysiłków Unii Europejskiej w zakresie rozpowszechnienia ponadnarodowego poczucia przynależności - przykładem może tu być projekt Erasmus - wyobrażona wspólnota europejska pozostaje jednak wciąż w trakcie tworzenia. Liczne problemy, które napotykają na swojej drodze młodzi migranci, sprowadzają się do poczucia odrzucenia, odmienności, a przede wszystkim marginalizacji w społeczeństwie, w którym tymczasowo żyją. Właśnie proces marginalizacji mniejszości etnicznych jest jednym z elementów zapowiadających nadejście nowego nacjonalizmu, jak wykazuje Gellner (1983). Ponadto poczucie przynależności do wspólnej tożsamości europejskiej w wielu przypadkach pojawia się tylko w momencie kontaktu z osobami spoza Europy. Co ciekawe, w kilku wypowiedziach Ukraina i Rosja zostały uznane za rzeczywistość kulturową odrębną od Europy. 
Przeprowadzone wywiady nie umożliwiają wysnucia wyczerpujących wniosków, naświetlają jednak i poddają pod dyskusję rzeczywistą rozbieżność pomiędzy procesem integracji ekonomicznej i finansowej Europy a efektywną integracją kulturową pomiędzy narodami.

Ttumaczenie z jezzyka włoskiego

Monika Czerniak

\section{BIBLIOGRAFIA}

Anderson B. (1983), Imagined Communities: Reflections on the Origin and Spread of Nationalism, Verso, London - New York.

Berry J.W. (1990), Psychology of Acculturation, [w:] Nebraska Symposium on motivation, vol. 37, ed. J. Berman, University of Nebraska Press, Lincoln.

Berry J.W. (1997), Immigration, Acculturation and Adaptation, „Applied Psychology: An International Review" no. 46.

Bettin Lattes G., Bontempi M. et al. (2011), Generazione Erasmus?, Firenze University Press, Firenze.

Clifford J. (1994), Diasporas, „Cultural Anthropology” no. 3.

Gellner E. (1983), Nations and Nationalism, Blackwell, Oxford.

Habermas J. (1998), L'inclusione dell'altro, Feltrinelli, Milano.

Inguglia C., Lo Coco A. (2004), Psicologia delle relazioni interetniche, Carocci, Roma.

Schiller G. (1994), Nations Unbound: Transnational Projects, Postcolonial Predicaments and Deterritorialized Nation-States, Gordon and Breach/Routledge.

Schütz A. (1962), The Problem of Social Reality, [w:] idem, Collected Papers, Martinus Nijhoff, The Hague.

Serra C. (2011), Indicazioni di V(u)oto, Laurum, Grosseto.

Shils E. (1960), Political Development in the New States, "Comparative Studies in Society and History" no. 2. 